\title{
THE CORRELATION BETWEEN THE USE OF BATTERY PERCUSSION INSTRUMENTS WITH THE LOW BACK PAIN MYOGENIC COMPLAINT OF THE PERCUSSION DIVISION PLAYERS OF THE MARCHING BANDS IN DENPASAR AND BADUNG
}

\author{
Putu Intan Noviyanti ${ }^{1}$, Ni Luh Nopi Andayani ${ }^{2}$, M. Widnyana ${ }^{3}$, Luh Made Indah Sri Handari \\ Adiputra $^{4}$ \\ ${ }^{1}$ Undergraduate and Professional Physiotherapy Study Program, Faculty of Medicine, Udayana \\ University \\ ${ }^{2,3}$ Physiotheraphy Department, Medical Faculty, Udayana University \\ ${ }^{4}$ Phisiology Department, Medical Faculty, Udayana University
}

E-Mail: Intannov.9b@gmail.com

\begin{abstract}
Background: Low back pain (LBP) is a kind of complaint which is easily found in human's daily life. An activity of carrying something can be one of factors causing the low back pain. Many people uphold some things more than the normal limit by using a wrong way and even doing it for a long duration. A battery percussion player is required to uphold and sustain a battery percussion instrument with an upright standing position and for quite a long time. It can cause the low back pain. Purpose: to find out the correlation between the use of battery percussion instruments with the low back pain myogenic complaint of the percussion division players. Method: This study used an observational analytic method with cross sectional approach which applied a saturation sampling technique. The number of the sample was 90 people divided into 3 groups: snare drum, quint tom/ multi toms and bass drum in which each group contained of 30 people. The data collection was conducted by filling out a questionnaire to diagnose and measure the pain scale with VAS. The hypothesis test was done using bivariate analysis with a chi-square test. Result: The result of the study shows that the bivariate analysis with the chi-square test finds out that the value is $\mathrm{p}<0.05$. Furthermore, the low back pain percentage of the snare drum is $63.4 \%$; the quint tom/multi toms is $100 \%$; and, the bass drum is $90.1 \%$. Conclusion: Based on the result of the study, it can be concluded that there is a correlation between the use of battery percussion instruments and the low back pain myogenic complaint of the percussion division players of the marching bands in Denpasar and Badung.
\end{abstract}

Key Words: Low Back Pain, Marching Band, Battery Percussion, VAS.

\section{HUBUNGAN ANTARA PENGGUNAAN ALAT BATTERY PERCUSSION DENGAN KELUHAN LOW BACK PAIN MYOGENIC PADA PEMAIN MARCHING BAND DIVISI PERKUSI DI DENPASAR DAN BADUNG}

\section{ABSTRAK}

Pendahuluan: Low back pain (LBP) merupakan keluhan yang sering dijumpai pada kehidupan sehari-hari. Kegiatan mengangkat dapat menjadi salah satu penyebab terjadinya low back pain. Banyak orang mengangkat barang melebihi batas normal, cara mengangkat barang yang salah 
bahkan mengangkat dalam waktu yang lama. Pemain battery percussion diharuskan mengangkat dan menopang alat dengan posisi berdiri tegak dan dengan durasi yang cukup lama. Hal tersebut dapat memicu terjadinya low back pain. Tujuan Penelitian: untuk mengetahui hubungan antara penggunaan alat battery percussion dengan keluhan low back pain myogenic pada pemain marching band divisi perkusi. Metode: Penelitian ini adalah penelitian analitik observasional dengan pendekatan cross sectional menggunakan teknik pengambilan sampel yaitu dengan sampel jenuh. Sampel penelitian berjumlah 90 orang yang dibagi menjadi 3 kelompok, yaitu kelompok pemain snare drum, quintom/multitoms dan bass drum, tiap kelompok berjumlah 30 orang. Pengumpulan data dilakukan dengan pengisian kuesioner untuk penegakan diagnosis dan pengukuran skala nyeri dengan VAS. Uji Hipotesis menggunakan analisis bivariat dengan uji chi-square. Hasil: Hasil penelitian menunjukkan pada analisis bivariat dengan uji chi-square didapatkan nilai $p<0,05$. Kemudian persentase low back pain pada snare drum sebesar 63,4\%, pada quintom/multitoms sebesar 100\% dan pada bass drum sebesar 90,1\%. Kesimpulan: Berdasarkan hasil penelitian tersebut dapat disimpulkan bahwa terdapat hubungan antara penggunaan alat battery percussion dengan keluhan low back pain myogenic pada pemain marching band divisi perkusi di Denpasar dan Badung. Kemudian alat yang paling berhubungan menyebabkan low back pain yaitu quintom/multitoms.

Kata Kunci: Low Back Pain, Marching Band, Battery Percussion, VAS.

\section{INTRODUCTION}

The activities of lifting and carrying something are often found in the daily life. Many people uphold some things more than the normal limit by using a wrong way and even doing for a long duration. This kind of activity, unfortunately, is done continuously. It will trigger the risk of low back pain. Low back pain (LBP) is a type of complaint which is often found in human's daily life. ${ }^{1}$ That kind of activity can be found in some various places and one of them is in an extracurricular or student organization.

Marching Band is one of extracurricular or student organization which exists in Denpasar and Badung. ${ }^{2}$ It is a group of people who plays a or some song(s) using some combinations of instruments (flute, percussion, and a number of pit instruments) together. ${ }^{3}$ In the marching band, the players which are categorized to have more burden in carrying the instruments are the battery percussion players. The battery percussion players must uphold a heavy instrument without any helping tools and in an upright standing position. The battery percussion instruments consist of snare drum, quint tom/multi toms and bass drum. The snare drum is $13 \times 11$ and $14 \times 12$ inch circle instrument and has between 6-8 kilograms of weight. The bass drum is a big circle instrument with 24-26 inch size and 6-12 kilograms weight. Lastly, the quint tom is a percussion instrument which has in total $5 \mathrm{big}$ and small circles with $10,12,13,14$, and $6 / 8$ inch standard size and $17.5 \mathrm{~kg}$ average weight. $^{4}$

The marching band players usually conduct a routine practice once a week for 3-4 hours. If there is an event or competition, they will do practice 3-4 times in a week or even every day. The act of carrying the heavy instruments done by the battery percussion players can cause an injury or a pain in their low back because the back muscles and bone have an important role in helping the players to carry the heavy instruments. The use of the back muscles and bone which is more than the normal limit and the wrong way in carrying the instruments may cause the battery percussion players have low back pain complaint due to a muscle spasm. ${ }^{5}$

\section{RESEARCH METHODS}

The study used observational analytic with cross sectional approach. This study was conducted in June 2019 - January 2020. The research was done in all junior high schools, senior high schools, and universities in 
Denpasar and Badung which had the extracurricular/student organization of marching band. The number of samples was 30 people for each battery percussion group; therefore, the sample was 90 people in total which were obtained by using probability sampling technique.

The sample had fulfilled the inclusion criteria in which they must be 13-25 years old male whose body mass index is normal, have played the battery percussion instruments for minimum 6 months, and agree to be the sample of the research by filling an informed consent; moreover, they must not include into the exclusion criteria in which they did not have any scars around their waist (by checking their waist area with a permission from them) and any spine disorders such as kyphosis, lordosis and scoliosis (by checking their physical characteristics or symptoms which were based on physiotherapy check which were later measured by using a plumb line).

In this study, the battery percussion player was an independent variable. On the other hand, the low back pain of the battery percussion player was a dependent variable. The variables which were controlled in the study were age, gender, and body mass index (BMI).

The study was started by giving information to the respondents related the objective, significance, and the procedure of the study which was continued with the informed consent filling, the interview related to the respondent's age, gender, and body mass index (BMI), and, lastly, the pain scale measurement using VAS (Visual Analogue Scale). The result of the pain scale measurement using VAS was 0 for no pain, 13 for mild pain, 4-6 for moderate pain, 7-9 controlled severe pain, and 10 for agonizing pain. The body mass index (BMI) measurement of the research sample was conducted by measuring the body weight using a balance and body height using microtoise. The results of those measurements were counted using the formula of $\mathrm{BMI}=\mathrm{BW} / \mathrm{BH}^{2}$; furthermore, the result of the calculation was categorized based on the BMI classification proposed by the Indonesian Health
Department 2010 which stated underweight for $<17$, normal for 18-25, overweight for 25.1-27, and obesity for $>30$.

The collected data of the study, furthermore, was analysed at a software namely Statistical Package for the Social Sciences (SPSS). The data analyses of the study were univariate analysis which aims at describing the sample characteristics in general and bivariate analysis using chi-square test aiming at finding out the correlation between the battery percussion player as the independent variable and the low back pain of the player as the dependent variable.

\section{RESULTS}

This study is conducted on the battery percussion players in junior high schools, senior high schools, and universities which have the extracurricular/student organization of marching band in Denpasar and Badung with the total sample is 90 people. The description of the sample characteristics such as the age, battery percussion instrument, and low back pain are obtained by conducting univariate analysis. Below is the table of the analysis result of the sample characteristics.

\section{The Research Sample Characteristics}

This study is conducted on the battery percussion players in junior high schools, senior high schools, and universities which have the extracurricular/student organization of marching band in Denpasar and Badung with the total sample is 90 people. The description of the sample characteristics such as the age, battery percussion instrument, and low back pain are obtained by conducting univariate analysis.

The analysis result of the sample characteristics can be seen in table 1 .

Table 1.

The Research Sample Characteristics

\begin{tabular}{|c|c|c|}
\hline Variable & $\begin{array}{c}\text { Frequenc } \\
\mathrm{y}(\mathrm{n})\end{array}$ & $\begin{array}{c}\text { Percentag } \\
\text { e }(\%)\end{array}$ \\
\hline
\end{tabular}




\begin{tabular}{lcc}
\hline Age & & \\
13-15 years old & 36 & 40 \\
16-18 years old & 37 & 41.1 \\
19-21 years old & 13 & 14.4 \\
22-25 years old & 4 & 4.5 \\
Battery percussion & & \\
instruments & & \\
$\quad$ Snare drum & 30 & 33.33 \\
Quintom/Multito & 30 & 33.33 \\
$\quad$ ms & & \\
$\quad \begin{array}{c}\text { Bass drum } \\
\text { Low Back Pain }\end{array}$ & 30 & 33.33 \\
$\quad$ Yes & 76 & 84.4 \\
$\quad$ No & 14 & 15.6 \\
\hline
\end{tabular}

The table 1 above shows that, from 90 research subjects, the samples who are 13-15 years old are 36 people (40\%); 16-18 years old are 37 people $(41.1 \%)$; 19-21 years old are 13 people (14.4\%), 22-25 years old are 4 people (4.5\%); and, the greatest number of sample is at the age of 16-18 years old which are 37 people $(41.1 \%)$. From the 90 research subjects, there are 30 people $(33.33 \%)$ play snare drum, 30 people (33.33\%) play quint tom/multi toms, and 30 people $(33.33 \%)$ play bass drum. Furthermore, from the 90 research subjects, it is found that there are 76 people $(84.4 \%)$ have low back pain. On the other hand, there are 14 people (15.6\%) do not have low back pain.

\section{Normality and Homogeneity Test}

The normality and homogeneity test can be seen in table 2 .

Table 2.

Normality and Homogeneity Test

\begin{tabular}{ccc}
\hline $\begin{array}{c}\text { Battery } \\
\text { Percussion } \\
\text { Instruments }\end{array}$ & $\begin{array}{c}\text { Normali } \\
\text { ty Test } \\
\text { (Saphiro } \\
\text { Wilk } \\
\text { Test) }\end{array}$ & $\begin{array}{c}\text { Homogenei } \\
\text { ty Test } \\
\text { (Lavene's } \\
\text { Test) }\end{array}$ \\
\hline $\begin{array}{c}\text { Snare Drum } \\
\text { Quintom/Multito } \\
\text { ms }\end{array}$ & 0.000 & \\
Bass Drum & 0.000 & 0,001 \\
\hline
\end{tabular}

In table 2. above, it can be seen that the significant value of the normality test is Snare Drum of 0,000, Quintom / Multitoms of 0,000 and Bass drum of 0.003 . The resulting value is smaller than 0.05 , it can be concluded that the data are not normally distributed. Then the homogeneity test above can be seen the resulting $p$ value of 0.001 . The $p$ value is less than 0.05 , it can be concluded that the data obtained are not the same or not homogeneous.

\section{Hypothesis Test}

The result of the analysis between the two variables of the battery percussion player as the independent variable and the low back pain of the battery percussion player as the dependent variable using the bivariate analysis with chi-square test can be seen in the table below.

The Correlation between the Use of Battery Percussion Instruments and the Low Back Pain Myogenic (No Pain-Moderate Pain) can be seen in table 3 .

Table 3.

The Correlation between the Use of Battery Percussion Instruments and the Low Back Pain Myogenic (No Pain-Moderate Pain)

\begin{tabular}{ccccccc}
\hline Battery & \multicolumn{5}{c}{ VAS Pain Scale } \\
\cline { 2 - 7 } $\begin{array}{c}\text { Percussi } \\
\text { on }\end{array}$ & $\begin{array}{c}\text { No } \\
\text { Pain }\end{array}$ & \multicolumn{2}{c}{$\begin{array}{c}\text { Mild } \\
\text { Pain }\end{array}$} & \multicolumn{2}{c}{$\begin{array}{c}\text { Moderate } \\
\text { Pain }\end{array}$} \\
\cline { 2 - 7 } $\begin{array}{c}\text { Instrum } \\
\text { ents }\end{array}$ & $\mathrm{N}$ & $\%$ & $\mathrm{~N}$ & $\%$ & $\mathrm{~N}$ & $\%$ \\
\hline Snare & 1 & 36 & 8 & 26 & 11 & 36.7 \\
Drum & 1 & .7 & & .7 & & \\
Quinto & & & & & 7 & 23.3 \\
m/Multi & - & - & - & - & & \\
toms & & & & & & \\
Bass & 3 & 10 & 1 & 36 & 11 & 36.7 \\
Drum & 1 & 15 & 1 & 21 & 29 & 32.2 \\
Total & 1 & 1 & .6 & 9 & .1 & 29 \\
\hline
\end{tabular}

The Correlation between the Use of Battery Percussion Instruments and the Low Back Pain Myogenic (Controlled Severe PainAgonizing Pain) can be seen in table 4. 
Table 4.

The Correlation between the Use of Battery Percussion Instruments and the Low Back Pain Myogenic (Controlled Severe PainAgonizing Pain)

\begin{tabular}{|c|c|c|c|c|c|c|}
\hline \multirow{3}{*}{$\begin{array}{l}\text { Battery } \\
\text { Percussi } \\
\text { on } \\
\text { Instrum } \\
\text { ents }\end{array}$} & \multicolumn{6}{|c|}{ VAS Pain Scale } \\
\hline & \multicolumn{2}{|c|}{$\begin{array}{l}\text { Contro } \\
\text { lled } \\
\text { Severe } \\
\text { Pain }\end{array}$} & \multicolumn{2}{|c|}{$\begin{array}{l}\text { Agonizi } \\
\text { ng Pain }\end{array}$} & \multicolumn{2}{|c|}{ Total } \\
\hline & $\mathrm{N}$ & $\%$ & $\mathrm{~N}$ & $\%$ & $\mathrm{~N}$ & $\%$ \\
\hline $\begin{array}{l}\text { Snare } \\
\text { Drum }\end{array}$ & - & - & - & - & 30 & 100 \\
\hline $\begin{array}{l}\text { Quinto } \\
\text { m/Multi } \\
\text { toms }\end{array}$ & $\begin{array}{l}2 \\
1\end{array}$ & 70 & 2 & $\begin{array}{l}3 \\
0\end{array}$ & 30 & 100 \\
\hline $\begin{array}{c}\text { Bass } \\
\text { Drum }\end{array}$ & 5 & $\begin{array}{l}16 \\
.7\end{array}$ & - & - & 30 & 100 \\
\hline Total & $\begin{array}{l}2 \\
6\end{array}$ & $\begin{array}{c}28 \\
.9\end{array}$ & 2 & $\begin{array}{l}2 \\
.2\end{array}$ & 90 & 100 \\
\hline
\end{tabular}

In the table 3 and table 4 there is an Asymp.Sig. (2-sided) value or value $\mathrm{P}$ which is 0.000 in the result of chi-square test. The value $\mathrm{p}<0.05$ means that there is a significant correlation between the use of battery percussion instruments and the low back pain myogenic complaint of the percussion division players of the marching band in Denpasar dan Badung. In the snare drum group, there are 11 people $(36.7 \%)$ having no low back pain, 8 people $(26.7 \%)$ having mild pain, 11 people $(36.7 \%)$ having moderate pain and none of them is categorized to have controlled severe pain and agonizing pain. In the quint tom/multitoms group, none of them is classified to have no pain and mild pain; however, there are 7 people $(23.3 \%)$ have moderate pain, 21 people $(70 \%)$ have controlled severe pain, and 2 people (30\%) have agonizing pain. In the bass drum group, there are 3 people (10\%) have no pain, 11 people $(36.7 \%)$ have mild pain, 11 people $(36.7 \%)$ have moderate pain, 5 people $(16.7 \%)$ have controlled severe pain, and none of them has agonizing low back pain.
The Percentage of the Number of Low Back Pain Myogenic Patient can be seen in table 6.

Table 6.

The Percentage of the Number of Low Back Pain Myogenic Patient

\begin{tabular}{ccc}
\hline \multirow{2}{*}{ Group } & \multicolumn{2}{c}{ Analysis Results } \\
\cline { 2 - 3 } & $\mathrm{N}$ & $\%$ \\
\hline Snare Drum & 19 from & 63.4 \\
$\begin{array}{c}30 \\
\text { Quintom/Mult } \\
\text { itoms }\end{array}$ & $\begin{array}{c}30 \text { from } \\
30\end{array}$ & 100 \\
Bass Drum & $\begin{array}{c}27 \text { from } \\
30\end{array}$ & 90.1 \\
\hline
\end{tabular}

The conclusion can be obtained based on the table 3 until table 6 is that there is a correlation between the use of battery percussion instruments and the low back pain myogenic complaint of the percussion division player of the marching band in Denpasar and Badung. Additionally, among the three groups of the battery percussion instruments, the quint tom/ multi toms more correlates with the low back pain myogenic complaint of the percussion division players of the marching band in Denpasar and Badung.

\section{DISCUSSIONS}

\section{Characteristics of the Research Sample}

This study aims at finding out whether there is a correlation between the use of battery percussion instruments and the low back pain myogenic complaint of the percussion division player of the marching band in Denpasar and Badung. The characteristics of the research subject consist of a group with the age range between 13-25 years old. The table 1 shows that, from the total of 90 people, the group with the age range between 16-18 years old has the greatest number of suffering low back pain which is 37 people. From all the research subjects, there are $84.4 \%$ of them have low back pain. The low back pain is the most frequent cause which inhibits the young and middle-aged people's activities. ${ }^{6}$ The study 
conducted in Poland shows that, from 1,089 respondents at the age of 10-19 years old, the prevalence of the back pain is 830 or $76.2 \%$ of them especially in the lumbar segment which is $74.8 \%$ and $44.7 \%$ dominant mild pain.

Based on the BMI characteristics, the study uses the normal criteria of BMI. The body weight, body height, and body mass index have a strong correlation with the risk of musculoskeletal disorder ${ }^{7}$; therefore, the study uses the normal criteria of BMI in the inclusion criteria in order to eliminate the bias factor which can happen if the sample has underweight, overweight, or obesity criteria of BMI. Meanwhile, the characteristics of the gender which is used in the study is male. It is because, physiologically, the female muscle ability is weaker than the male one. ${ }^{8}$ The study uses the gender of male in order to avoid physiological difference factor between the male and female muscle ability which can influence the low back pain that they feel.

\section{The Correlation between the Use of Snare Drum Type of Battery Percussion with the Low Back Pain Myogenic Complaint}

The result of the statistical test shows that, from 30 research subjects $(100 \%)$ of the snare drum group, there are 11 people $(36.7 \%)$ with no pain, 8 people $(26.7 \%)$ with mild pain, 11 people $(36.7 \%)$ with moderate pain, and none of them is categorized to have controlled severe and agonizing pain. The number of the low back pain patient in this group is $63.4 \%$. The result of the bivariate analysis using the chi-square test shows the value of $p<0.05$. It means that there is a significant correlation between the snare drum type of battery percussion and the low back pain myogenic complaint of the percussion division players of marching bands in Denpasar and Badung.

The snare drum is a marching band instrument which is categorized into one of battery percussion instruments played by being uphold and used for a quite long duration while forming various lines of march. The technique of playing this kind of battery instrument is by beating the upside of it with the same hand position. Moreover, this instrument has $6 \mathrm{~kg}$ of weight. ${ }^{4}$

All battery percussion players including the snare drum players often play the instruments while standing upright because they are required to form various lines of march. This is one factor causing the low back pain of the snare drum players. Besides because of the weight of the snare drum instrument and the long duration of carrying it, the gesture and position of the snare drum player are also the factors of increasing the risk of the low back pain.

The study also finds out that there are some snare drum players who do not have any low back pain complaints. This is because, when the practice is done, there are some research subjects who come late; hence, the duration of carrying the snare drum instrument of each player is different one to the other. Another factor that may cause the players to have no low back pain is that they have ever got the pain yet they ignore it because they think it is only a usual thing.

\section{The Correlation between the Use of Quint Tom / Multi Toms Type of Battery Percussion with the Low Back Pain Myogenic Complaint}

Based on the result of statistical test, it is found that, from the 30 research subjects $(100 \%)$ of the quint tom / multi toms group, there is none of them who is categorized to have no pain and mild pain. However, there are 7 players (23.3\%) with moderate pain, 21 players $(70 \%)$ with controlled severe pain, and 2 players $(6.7 \%)$ with agonizing pain. The number of low back pain patient in this group is $100 \%$. The result of the bivariate analysis using the chi-square test shows the value of $p$ $<0.05$. This means that there is a significant correlation between the quint tom / multi toms type of battery percussion and the low back pain myogenic complaint of the percussion division players of marching bands in Denpasar and Badung.

Like the snare drum, the quint tom (also known as multi toms) is also a part of battery percussion instrument. The weight of the quint tom/multi toms instrument is around 17 
kilograms. Therefore, this instrument is heavier than the snare drum and bass drum.

The weight of the instrument can be one of factors causing the players have low back pain complaint if they do not pay attention to the duration and repetition of using it. The complaint of musculoskeletal generally happens because of the excessive muscle contraction as the result of doing a hard work for a long duration. If the muscle contraction is more than $20 \%$, the blood circulation to the muscles will decrease which can reduce the oxygen supply to the muscle and metabolism system can be stopped. It results in the accumulated lactate which causes the pain of the muscle.

Similar with the snare drum, the quint tom/multi toms instrument is also played by being carried while forming the line of march. The difference of the quint tom/ multi toms with the snare drum is located in their weight, in which the quint tom/ multi toms is heavier. Additionally, their playing technique is also different: in playing the quint tom/multi toms, the player beats five sides of the instrument while in snare drum only one.

The lumbar positions which are at risk of getting low back pain are rotation, front flexion, and carrying the heavy instrument with the outstretched arms position. The position of carrying the instrument causes the compression of the muscle and the burden load; hence, the discus pressure increases and triggers the pain. ${ }^{7}$ Doing something in the same position for a long time either standing or sitting makes an inconvenience. Working with standing gesture for a long duration will make the worker always try to balance his body position; therefore, it causes a static workload on the back and leg muscles. ${ }^{9}$

Looking at the weight of the instrument combined with the duration and frequency of using it, the habitual and the condition of the player while playing it are the factors that can cause the low back pain. The result of this study show that all quint tom/ multi toms players have low back pain complaint. Therefore, it can be said that the quint tom/ multi toms type of battery percussion instrument has a significant correlation with the low back pain myogenic complaint of the percussion division players of marching bands in Denpasar and Badung.

\section{The Correlation between the Use of Bass Drum Type of Battery Percussion with the Low Back Pain Myogenic Complaint}

The statistic test shows that, from 30 research subjects $(100 \%)$ in the bass drum group, there are 3 people (10\%) with no pain, 11 people $(36.7 \%)$ with mild pain, 11 people $(36.7 \%)$ with moderate pain, 5 people $(16.7 \%)$ with controlled severe pain, and none of them is with agonizing pain. . The number of low back pain patient in this group is $90.1 \%$. The result of the bivariate analysis using the chisquare test shows the value of $p<0.05$. This means that there is a significant correlation between the bass drum type of battery percussion and the low back pain myogenic complaint of the percussion division players of marching bands in Denpasar and Badung.

The bass drum, similar with the snare drum and quint tom/ multi toms, is also a kind of battery percussion instrument. Its weight is around 12 kilograms. Therefore, this instrument is heavier than the snare drum yet lighter than the quint tom/ multi toms. ${ }^{4}$

The bass drum is played similarly with the snare drum and quint tom/ multi toms: by carrying it while moving to form the line of march. The differences between the bass drum and the other two types of battery percussion instruments are in their weight and technique of beating the drum: by beating 2 sides of the instrument. Moreover, the bass drum players usually do some visual movements such as bowing and rotating body. ${ }^{9}$

Similar with the snare drum group, in the bass drum also has some research subjects who do have no low back pain. It is because those research subjects have the least working period among the other research subjects. Besides, when the practice is conducted, there are some research subjects who come late which causes the duration of carrying the instruments of each player different. Another factor which may cause the players to have no low back pain is that they have ever got the pain yet they 
ignore it because they think it is only a usual thing.

The Differences of the Correlation between the Use of Snare Drum, Quint Tom/ Multi Toms, and Bass Drum Type of Battery Percussion Instruments with the Low Back Pain Myogenic Complaint.

Based on the result of measuring the pain scale using VAS, from the 90 research subjects, there are 76 subjects $(84.4 \%)$ have low back pain; otherwise, there are 14 subjects $(15.6 \%)$ have no low back pain. In the snare drum group, in which there are 30 people in total, $63.4 \%$ of them have low back pain. In the quint tom/multitoms group, in which there are 30 people in total, all of them have low back pain $(100 \%)$. In the bass drum group with 30 people in total, $90.1 \%$ of them have low back pain. The result of the bivariate analysis using the chi-square test finds out the value $\mathrm{p}<0.05$. This result shows that there is a correlation between the use of battery percussion instruments and the low back pain myogenic complaint of the percussion division players of the marching bands in Denpasar and Badung. The weight of the instruments is one of factors which causes the musculoskeletal disorder. The risky activity of carrying a heavy thing needs to pay attention to the duration and the frequency of the things being carried. ${ }^{10}$ The result of the study also shows that the quint tom / multi toms instrument is more impactful in causing low back pain to the research subjects. It is because quint tom / multi toms is the heaviest instrument among the other battery percussion instruments. Besides due to its weight, the position of playing the quint tom/ multi toms that the players often do visual bowing, leaning left/right, and rotating body while playing the instrument also can be the factor of causing low back pain to the players.

A long duration activity with the static muscle contraction will increase the pressure in the blood vessels. The musculoskeletal complaint generally happens because of the excessive muscle contraction as the result of doing a hard work for a long duration. If the muscle contraction is more than $20 \%$, the blood circulation to the muscles will decrease which can reduce the oxygen supply to the muscle and metabolism system can be stopped. It results in the accumulated lactate acid which causes the pain of the muscle. ${ }^{8}$ This is based on the condition of the quint tom/ multitoms players who often do some movements such as visual bowing and rotating their body which are never done by the snare drum and bass drum players.

Besides the weight of the instruments and the habitual of the players, the duration of the players carrying and using the instruments is also the factor of causing the low back pain complaint. The longer people carry a heavy thing, the longer they give burden to their low back; therefore, the risk of getting the low back pain is higher. This is based on the previous study which states that wrong body gesture which often becomes a habitual and some hard activities such as doing something by standing for 1 hour in a day or sitting for 2 hours in a day can also increase the risk of the low back pain. ${ }^{11}$ The study conducted by Adiatmika, IPG, et. al. in 2007 finds out that there is a musculoskeletal complaint after the body treatment decreases both in quality and quantity. The treatment influences the decrease of musculoskeletal complaint from 33.03+2.73 into $31.30+3.49$ ( $\mathrm{p}<0.05)$. Another study states that in the case of standing for a long duration, the human's body can only tolerate to keep standing in the same position only for 20 minutes. If it is more than that, the tissue elasticity will reduce, the muscle pressure will increase and the pain in the back will appear.

\section{RESEARCH WEAKNESS}

The weakness of this study is that it only controls the age, gender and BMI variables. Future studies are expected to add control variables such as duration of play, duration of lifting equipment, smoking habits, etc.

\section{CONCLUSION}

Based on the results of the study using the chi-square test, it can be concluded that: 
1. There is a correlation between the use of battery percussion instruments and the low back pain myogenic complaint of the percussion division players of the marching bands in Denpasar and Badung.

2. From the three groups of the battery percussion instruments, the quint tom/ multi toms has more correlation with the low back pain myogenic complaint of the percussion division players of the marching band in Denpasar and Badung.

\section{REFERENCES}

1. Demoulin C, (2012). Eff ectiveness of preventive back educational interventions for low back pain: a critical review of randomized controlled clinical trials. Eur Spine

Journal.http://www.ncbi.nlm.nih.gov/pub med/ 00586-012-2445-2.

2. Marko. 2015. Marching Band Sebagai Pendidikan Berkarakter: Sebuah Solusi Komprehensif Pendidikan Non-Formal Bagi Remaja. New Zealand. Victoria University of Wellington.

3. Arifin. 2013. Penerapan Latihan Dasar Percussion Line Pada Marching Band UGM Yogyakarta. Yogyakarta. Accessed on December 10, 2018.

4. Wulandari, Astrid Nugrahani. 2011. Perancangan Harness Dengan Pendekatan Ergonomi Di Marching Band Sebelas Maret Surakarta. Surakarta. Accessed on December 10, 2018 from digilib.uns.ac.id

5. Nureka, Restyan Puspa. 2016. Perbedaan Efektifitas Thermotherapy Dan Coldtherapy Terhadap Penurunan Nyeri Akibat Spasme Otot. University Of Muhammadiyah Malang.
6. Eleanor Bull dan Graham Archard, 2007, Nyeri Punggung, Terjemahan oleh Juwalita Surapsari, Jakarta: Erlangga.

7. Wahyuni, L GD Ayu Sri Nadi. 2015. Sikap Duduk Ergonomis Mengurangi Low back pain Non Spesifik Pada Mahasiswa Program Studi Fisioterapi Fakultas Kedokteran Universitas Udayana [Skripsi]. Denpasar: Universitas Udayana.

8. Tarwaka, Sholichul HA Bakri, Lilik Sudiajeng. 2004, Ergonomi Untuk Keselamatan Kesehatan Kerja dan Produktivitas, Surakarta: UNIBA press.

9. Septa Diana, Riza. 2012. Hubungan Sikap Kerja Berdiri Dengan Keluhan Muskuloskeletal Pada Pekerja Bagian Weaving Di Pt. Delta Merlin Dunia Tekstil Kebakkramat Karanganyar. Surakarta. Accessed on Desember 13, 2018 from Digilib.uns.ac.id

10. Defriyan. 2011. Faktor-Faktor Yang Berhubungan Dengan Keluhan Low back pain Pada Proses Penyulaman Kain Tapis Di Sanggar Family Art Bandar Lampung Tahun 2011. Jakarta.

11. Harun. 2013. Pengaruh Neuromuscular Technique Terhadap Perubahan Nyeri Otot Piriformis Pada Gangguan Biomekanik Dan Degeneratif Lumbal Di Klinik Physiosakti Dan Medisakti Makassar. Makasar. Universitas Hasanuddin.

12. Kedra dkk. 2013. Epidemiology of Back Pain in Children and Youth aged 10-19 from the Area of the Southeast of Poland. Biomed research international.

13. Natosba, Jum. 2016. Pengaruh Posisi Ergonomis Terhadap Kejadian Low Back Pain Pada Penenun Songket Di Kampung BNI 46. Jurnal Keperawatan Sriwijaya;3(2). Juli 2016 